\title{
SOLAR ASSISTED PHOTO FENTON FOR COST EFFECTIVE DEGRADATION OF TEXTILE EFFLUENTS IN COMPARISON TO AOPS
}

\author{
DURR-E-SHAHWAR ${ }^{1, *}$ \\ ABDULLAH YASAR ${ }^{2}$ \\ SUMAIRA YOUSAF
}

${ }^{1}$ College of Earth \& Environmental Sciences
University of the Punjab, Lahore, Pakistan
${ }^{2}$ Sustainable Development Study Centre
GC University, Lahore, Pakistan

*to whom all correspondence should be addressed: e-mail: shahwar6@gmail.com

\section{ABSTRACT}

Solar assisted Photo Fenton was compared with advanced oxidation processes for their color and COD removal efficiency and cost effectiveness. $\mathrm{H}_{2} \mathrm{O}_{2}$ alone appeared to be inefficient to reduce color and COD content of any effluent. The performance of Fenton process was slightly better, color and COD removals were $45 \%$ and $63 \%$ respectively. Photo Fenton treatment of blue effluent resulted into color and COD removal of $56 \%$ and $66 \%$ respectively. In case of black effluent, the removal of these parameters was $39 \%$ and $84 \%$ respectively. However, application of solar radiation (18 hours) resulted in substantial color and COD removal (i.e. $52 \%$ and $88 \%$ respectively for black effluent and $61 \%$ and $85 \%$, respectively for blue effluent). Solar assisted photo Fenton proved as the most energy and cost effective (100 to 150 times less as compared to UV/Fe/ $\mathrm{H}_{2} \mathrm{O}_{2}$ and $\mathrm{O}_{3}$ ) process among all AOPs, although ozone completely decolorized the effluent and showed more than $87 \%$ COD removal in an alkaline medium $(\mathrm{pH} 9)$ but at very high cost. The electrical energy requirements of the tested processes followed the increasing order UV/Fe/ $/ \mathrm{H}_{2} \mathrm{O}_{2}<\mathrm{O}_{3}<\mathrm{H}_{2} \mathrm{O}_{2}$ $<\mathrm{Fe} / \mathrm{H}_{2} \mathrm{O}_{2}<\mathrm{Solar} / \mathrm{Fe} / \mathrm{H}_{2} \mathrm{O}_{2}$.

KEYWORDS: Solar radiation, Ozone, Fenton, Photo Fenton, EE/O, Textile effluent.

\section{INTRODUCTION}

The textile dyeing and finishing industry is particularly known for its high water consumption in addition to the use of large amounts of chemicals (Arslan et al., 2000) characterizing textile industry wastewater as high COD, BOD, dissolved solids contents and high color (Sevimli and Kinaci, 2002). It is estimated that between 10 to $15 \%$ of the total dyes used in textile production and dyeing process is discharged in wastewater (Pavlostathis and Beydilli, 2005), rendering it toxic and unamenable to biological treatment (Bali et al., 2004). The extensive use of the synthetic dyes causes severe ecological problems as well (Shah et al., 2003). Especially, certain azo dyes are either toxic or can be converted (an-aerobically or in the presence of reducing agents) to carcinogenic and mutagenic compounds such as aromatic amines. Dyes contained by industrial effluents are often highly persistent and must be treated before discharging into water bodies (Shah et al., 2003; Konsowa, 2003).

There is variety of treatment methods, ranging from conventional physico-chemical methods to the most sophisticated advanced oxidation processes. Conventional methods are usually limited by high costs and production of large amount of sludge, which requires further treatment or deposition (Moreira et al., 2000; Alaton, 2003; Arslan et al., 2000) and use of biological techniques are also limited due to slow reaction rate and complexity. However, application of AOPs in the treatment of wastewaters has become popular. They are considered the most promising alternative to the traditional treatment technologies based on the generation of hydroxyl radicals, which can be used for non-specific oxidation of a wide range of organic compounds and color removal (Yasar et al., 2006; Huanga et al., 2008). Application of solar radiation for photo catalytic advanced oxidation 
process is also a very fascinating and fast developing area and is used for wastewater treatment (Wadley and Waite, 2002). The ultraviolet light or near UV light reacts with photo catalyst to produce hydroxyl radicals that rapidly destroy the chemical bonds of the contaminants (Wadley and Waite, 2002). Several dyes utilized by textile industries (including azo reactive dyes) have been successfully degraded by the above technique (Georgiou et al., 2002; Bali et al., 2004). Photolysis of Hydroxyl ferric ion can produce ferrous ion and hydroxyl radical. The ferrous ion Fe (II) reacts with molecular oxygen generating ferric ion and Hydrogen peroxide, then the ferric ion can go through the reactions. The hydroxyl radicals $\mathrm{OH} \bullet$ generated in this process can react with and oxidize most organic pollutants (Hu et al., 2003).

The objective of the present study was optimization of the oxidant concentrations as well as process conditions such as reaction $\mathrm{pH}$, temperature and exposure time in terms of overall COD and color removal (\%) efficiencies for an effective system to treat different dye bath effluents. Secondly to compare the efficiency of photo Fenton process using UV light sources of both natural (solar radiation) and artificial UV lamp. Finally cost benefit analysis of Advanced Oxidation Process in terms of energy requirements of ozonation, Fenton and Photo Fenton (both solar radiations UV light assisted Fenton and artificial UV light assisted Fenton) was carried out.

\section{EXPERIMENTAL MATERIAL AND METHODS \\ Sampling of Textile Wastewater}

Samples were taken from dye bath of black shade and blue shade respectively. Black shade is result of a recipe of yellow, black and red dyes, and blue shade is a combined effect of blue, red and yellow dyes. Tables 1 and 2 represent the characteristics of the effluents. Both samples were first filtered using filtration assembly. For Black effluent dilution was done by taking $200 \mathrm{ml}$ of filtered solution in an Erlenmeyer volumetric flask and filled up to $1000 \mathrm{ml}$ by distilled water and covered with aluminum foil. The blue effluent was not diluted.

Table 1. Characteristics of black effluent

\begin{tabular}{ll}
\hline Ciba yellow FN2R & $0.2575 \%$ \\
\hline Ciba Red FNR & $0.0041 \%$ \\
\hline Ciba Black WNN & $3.3990 \%$ \\
\hline Acetic Acid & $0.20 \mathrm{~g} \mathrm{I}^{-1}$ \\
\hline Glauber Salt & $80.0 \mathrm{~g} \mathrm{I}^{-1}$ \\
\hline Soda Ash & $30.0 \mathrm{~g} \mathrm{I}^{-1}$ \\
\hline $\mathrm{pH}$ & 10.5 \\
\hline Wavelength & $581 \mathrm{~nm}$ \\
\hline Reactive Group & Vinyl Sulphones $\left(--\mathrm{SO}_{2} \cdot \mathrm{CH}_{2} \cdot \mathrm{CH}_{2}\right.$. L) \\
\hline Temperature & $60{ }^{0} \mathrm{C}$ \\
\hline
\end{tabular}

Table 2. Characteristics of Ice blue effluent

\begin{tabular}{l|l}
\hline Lev blue EFFN & $0.1049 \%$ \\
\hline Lev Yellow CA & $0.0010 \%$ \\
\hline Lev Brill Red EBA & $0.0040 \%$ \\
\hline $\mathrm{H}_{2} \mathrm{O}_{2}(50 \%)$ & $3.0 \mathrm{~g} \mathrm{I}^{-1}$ \\
\hline Acetic Acid & $0.20 \mathrm{~g} \mathrm{I}^{-1}$ \\
\hline Glauber Salt & $20.0 \mathrm{~g} \mathrm{I}^{-1}$ \\
\hline Soda Ash & $7.0 \mathrm{~g} \mathrm{I}^{-1}$ \\
\hline PH & 10.5 \\
\hline Wavelength & $634 \mathrm{~nm}$ \\
\hline Reactive Group & Vinyl Sulphones $\left(--\mathrm{SO}_{2} \cdot \mathrm{CH}_{2} \cdot \mathrm{CH}_{2}\right.$.L) \\
\hline Temperature & $60{ }^{0} \mathrm{C}$ \\
\hline
\end{tabular}

\section{Hydrogen Peroxide Experiments}

The experimental assembly was consisted of a graduated Pyrex glass beaker and a magnetic stirring setup. The experiment was carried out in batch mode. Analytical grade $35 \%$ Hydrogen peroxide from Merck was used. A $200 \mathrm{ml}$ of effluent was taken in a Pyrex glass beaker. $\mathrm{H}_{2} \mathrm{O}_{2}$ was 
added to it by micropipette, temperature was set to $25^{\circ} \mathrm{C}$ by heating the wastewater and continuous stirring was done for 60 minutes. The color removal efficiency of $\mathrm{H}_{2} \mathrm{O}_{2}$ was determined by using UV visible spectrophotometer at the wavelength of $581 \mathrm{~nm}$ for Black effluent and $634 \mathrm{~nm}$ for Ice Blue effluent. COD reduction was investigated after stirring time of $10 \mathrm{~min}, 30 \mathrm{~min}$, and $60 \mathrm{~min}$.

\section{Fenton Experiments}

Filtered and diluted effluent was used in each run. The optimal dose of $\mathrm{H}_{2} \mathrm{O}_{2}$ was taken $0.8 \mathrm{ml} \mathrm{I}^{-1}$ and $1.0 \mathrm{ml} \mathrm{I}^{-1}$ for Black and Blue effluent respectively. $\mathrm{FeSO}_{4}$ was used as a catalyst (oven dried at $180^{\circ} \mathrm{C}$ for 4 hours). Stirring was carried out for first 5 minutes followed by 60 min settling time. The optimal dose of $\mathrm{H}_{2} \mathrm{O}_{2}$ was crossed check by keeping $\mathrm{FeSO}_{4}$ dose constant and varying $\mathrm{H}_{2} \mathrm{O}_{2}$ doses. The Fenton efficiency was also checked on different $\mathrm{pH}$ values i.e. $3,5,7$ and 9 by repeating the experiment.

\section{Photo-Fenton Experiments}

Three boxes made of transparent acrylic were used for the experimentation. Each box was $5 \times 5 \times$ $40 \mathrm{~cm}$ dimensions with a volume up to $1000 \mathrm{ml}$. Experiments were carried out in batch mode. A low pressure UV lamp of 108 watt power was used for irradiation. Optimal doses of $\mathrm{H}_{2} \mathrm{O}_{2} / \mathrm{FeSO}_{4}$ were added to sample and after 5 min stirring and one hour stay time; sample was exposed to 80 min irradiation. Color and COD removal efficiency of Photo-Fenton was checked at time interval of 20 $\min$ at $\mathrm{pH} 5,7$ and 9.

\section{Solar UV Assisted Photo-Fenton Experiments}

The same experimental setup was used for this process except the source of UV irradiation. Solar light was used to irradiate the effluent. After adding dose of $\mathrm{H}_{2} \mathrm{O}_{2} / \mathrm{Fe}^{+2}$ sample was stirred for 5 minutes and was exposed to sunlight for 3 days. Color and COD removal efficiencies were determined after every 2-hour at $\mathrm{pH} 7$ and 3 for both effluents.

\section{Ozonation}

Ozonation was carried out in a bubble column reactor. The internal diameter of reactor was $3.3 \mathrm{~cm}$. Ozone was generated by an ozone generator of Enaly (Model HGOZ/1000). Ozone was bubbled through effluent via diffusers placed at the bottom of the reactor. A $200 \mathrm{ml}$ industrial effluent was used in each run. In order to investigate the influence of $\mathrm{pH}$, experiments were conducted at $\mathrm{pH} 5,7$, 9 and 10. The efficacy of ozone treatment was determined at time varying from 10 to 60 minutes with 10 minutes interval by using UV visible Spectrophotometer at the wavelength of $581 \mathrm{~nm}$ for Black effluent and $634 \mathrm{~nm}$ for Blue effluent.

\section{Calculation of Energy Requirement and Cost}

Operating costs are directly affected by the treatment performance of the applied AOPs. To facilitate a comparison of reaction efficiencies, powerful scale-up parameters called EE/O (electrical energy required to remove a pollutant by one order of magnitude in one $\mathrm{m}^{3}$ of water or wastewater) was employed. EE/O demonstrates a direct link to the electrical efficiency of an advanced oxidation process, independent of the nature of the system and therefore allows for comparison of different AOPs technologies. Such figure-of-merit is necessary not only to compare AOP technologies but also to provide the requisite data for scale-up and economic analyses for comparison with conventional treatment. EE/O values have been calculated by applying the following empirical relationship (Azbar et al., 2004; Yasar et al., 2006).

$$
E E / O=\frac{P \times t \times 1000}{V \times 60 \times \log \frac{C_{0}}{C_{t}}}
$$

where:

$\mathrm{P}=$ the power input of the UV-lamp or the ozone generator or magnetic stirrer $(\mathrm{kW})$

$\mathrm{t}=$ oxidation time (minutes)

$V=$ the volume of the effluent (liter)

Co $=$ initial concentration of contaminant

$\mathrm{C}_{\mathrm{f}}=$ final concentration of contaminant 
Equation 1 is valid only for batch operation. Cost of AOPs can be calculated from Equation 2:

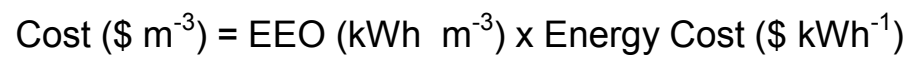

\section{RESULTS AND DISCUSSION}

The Efficiency of Hydrogen Peroxide

Figures 1 and 2 represent the effect of $\mathrm{H}_{2} \mathrm{O}_{2}$ dose on the removal efficiency (\%) of $\mathrm{H}_{2} \mathrm{O}_{2}$. It appears that efficiency of $\mathrm{H}_{2} \mathrm{O}_{2}$ alone is negligible and maximum color and $\mathrm{COD}$ removal at 60 min stirring time was only $21 \%$ and $32 \%$ for blue effluent and $21 \%$ and $44 \%$ for black effluent, respectively. There is an increase in the removal efficiency with an increase in the dose. However, that increase is just marginal. After the optimal dose, increase in the dose of $\mathrm{H}_{2} \mathrm{O}_{2}$ results into a decease of color and $\mathrm{COD}$ removal because of its $\mathrm{OH}$-radical scavenging property (Aleboyeh et al., 2005). Results reveal that blue color effluent is slightly resistant to $\mathrm{H}_{2} \mathrm{O}_{2}$ treatment.
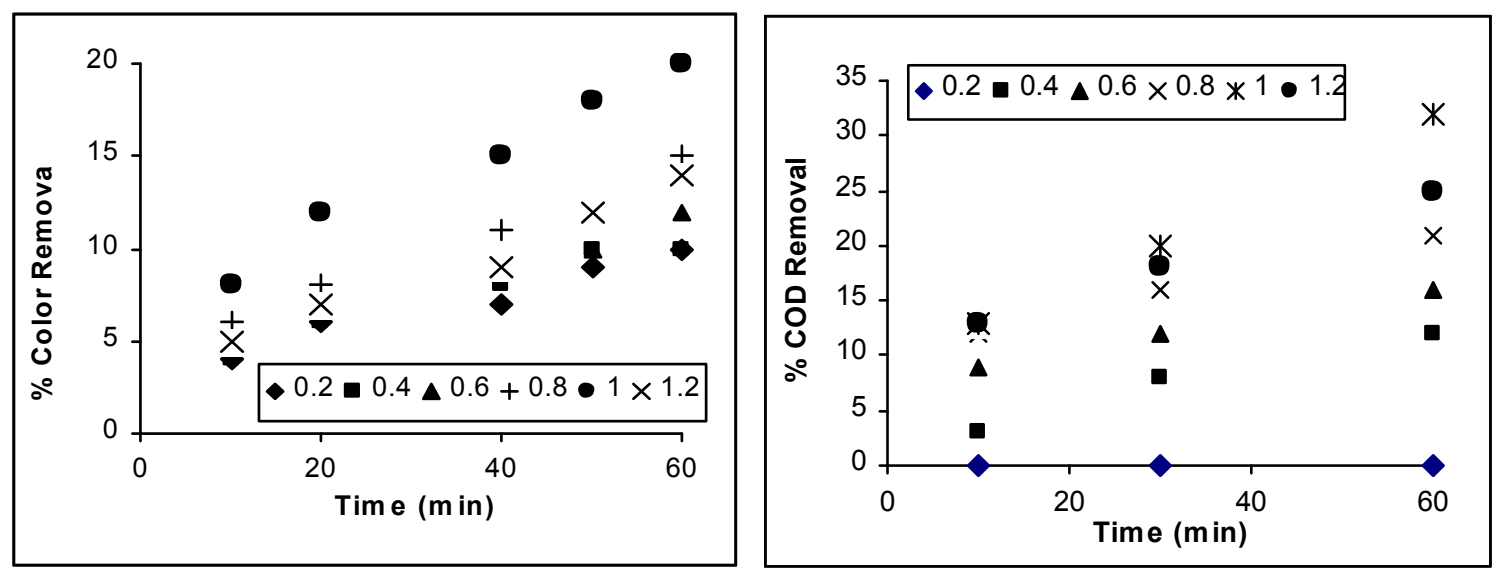

Figure 1. Efficiency of $\mathrm{H}_{2} \mathrm{O}_{2}$ alone for color and COD removal for blue effluent at $\mathrm{pH} 10.5$ $\mathrm{H}_{2} \mathrm{O}_{2}$ Dose: $0.2 \mathrm{ml} \mathrm{l}^{-1}, 0.4 \mathrm{ml} \mathrm{l}^{-1}, 0.6 \mathrm{ml} \mathrm{l}^{-1}, 0.8 \mathrm{ml} \mathrm{l}^{-1}, 1.0 \mathrm{ml}^{-1}, 1.2 \mathrm{ml} \mathrm{l}^{-1}$
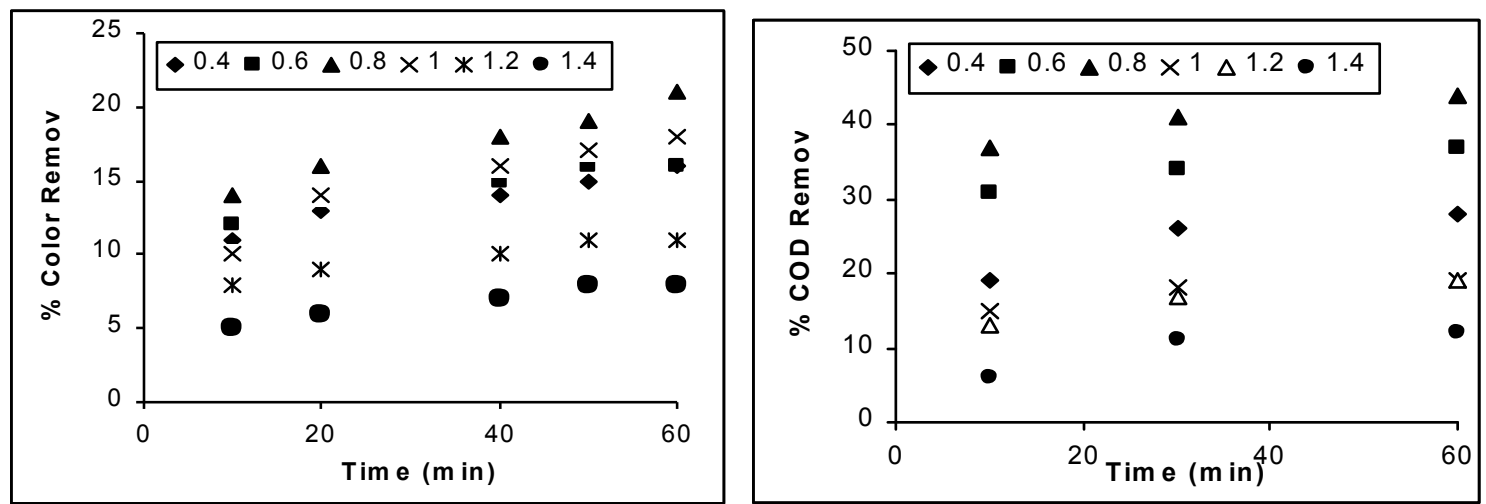

Figure 2. Efficiency of $\mathrm{H}_{2} \mathrm{O}_{2}$ alone on color and COD removal for black effluent at $\mathrm{pH} 10.5$ $\mathrm{H}_{2} \mathrm{O}_{2}$ Dose: $0.4 \mathrm{ml} \mathrm{l}^{-1}, 0.6 \mathrm{ml}^{-1}, 0.8 \mathrm{ml} \mathrm{l}^{-1}, 1.0 \mathrm{ml} \mathrm{l}^{-1}, 1.2 \mathrm{ml}^{-1}, 1.4 \mathrm{ml} \mathrm{l}^{-1}$

\section{Fenton Process}

The performance of $\mathrm{H}_{2} \mathrm{O}_{2}$ as an oxidant can be enhanced by generating highly activated species $(\mathrm{OH} \bullet)$ by adding iron salt to the effluent (Balcioglu and Arslan, 2001). It is evident from the results (Figures 3 and 4) that an increase in the concentration of $\mathrm{FeSO}_{4}$ increases the color and COD removal $(23 \%$ and $38 \%$ for blue effluent and $22 \%$ and $81 \%$ for black effluent respectively at $\mathrm{H}_{2} \mathrm{O}_{2} / \mathrm{Fe}$ ratio of 1:50 for blue effluent and 0.8:40 for black effluent). It is evident that an increase in the $\mathrm{FeSO}_{4}$ content beyond the optimal dose is associated with the decrease in the efficiency of Fenton process as most of the $\mathrm{H}_{2} \mathrm{O}_{2}$ dosage is consumed in the early stage of the Fenton reaction and unutilized quantity of iron salts left in the system, which contributes to an increase in the TDS content of the effluent thus decreasing the process efficiency. 

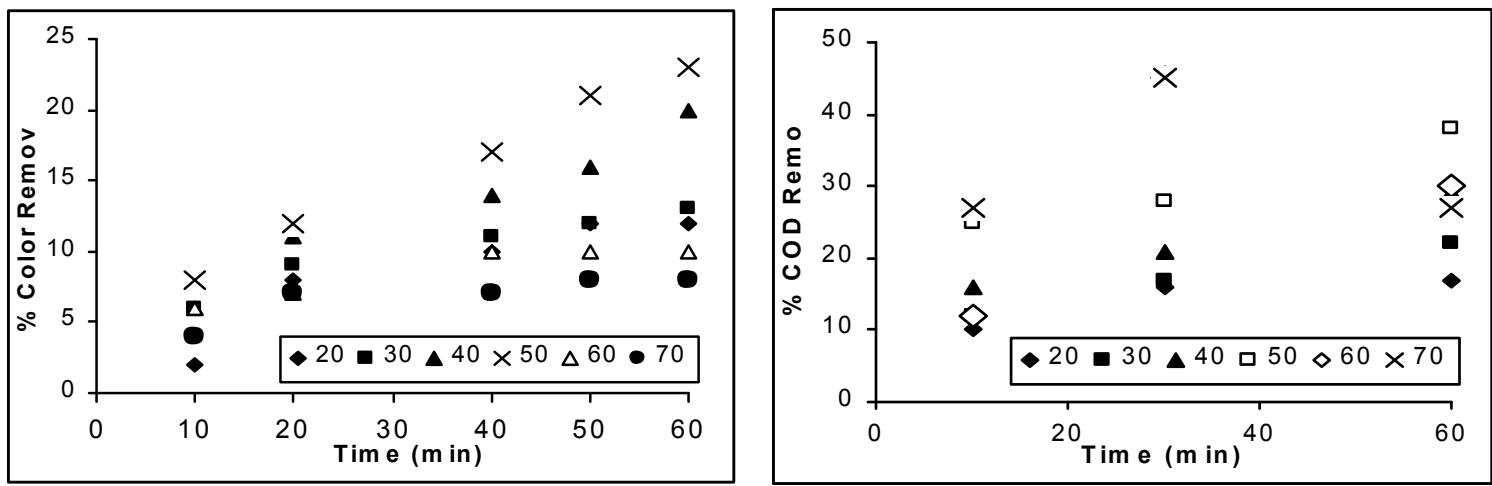

Figure 3. Efficiency of Fenton on color and $\mathrm{COD}$ removal for blue effluent at $\mathrm{pH} 7$ and $\mathrm{H}_{2} \mathrm{O}_{2}=1.0 \mathrm{ml} \mathrm{I}^{-1} ; \mathrm{FeSO}_{4}=20,30,40,50,60$ and $70 \mathrm{mg} \mathrm{l}^{-1}$
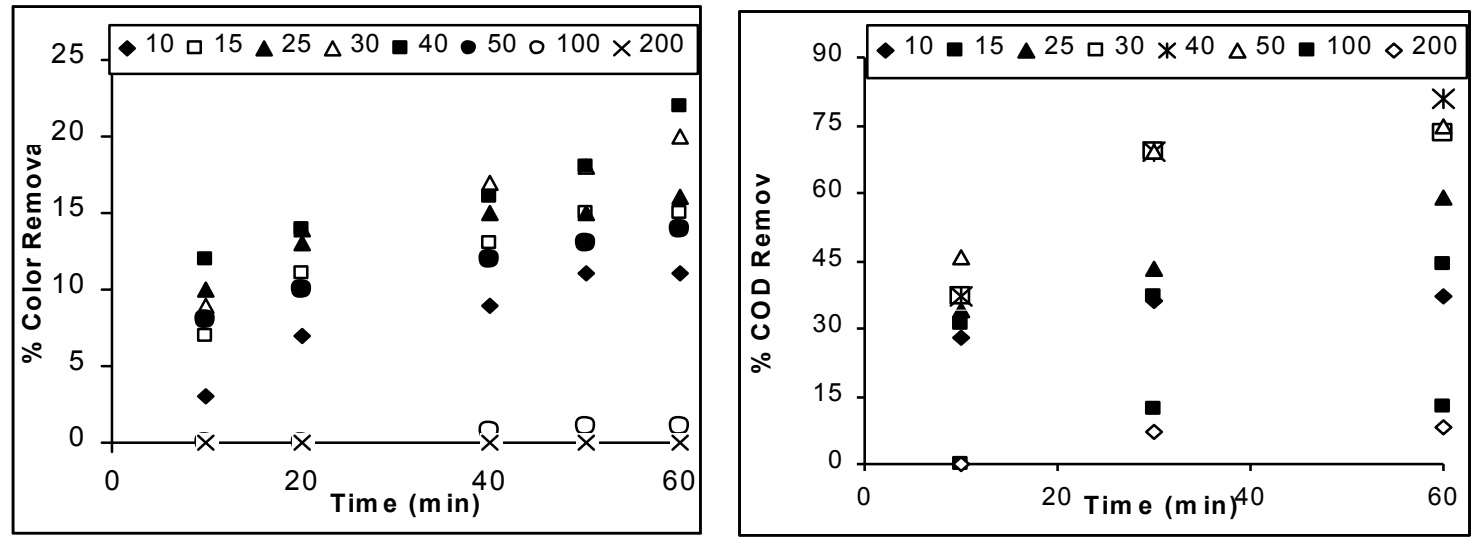

Figure 4. Efficiency of Fenton on color and COD removal for black effluent at $\mathrm{pH} 7$ and $\mathrm{H}_{2} \mathrm{O}_{2}=0.8 \mathrm{ml} \mathrm{I}^{-1} ; \mathrm{FeSO}_{4}=10,15,25,30,40,50,100$ and $200 \mathrm{mg} \mathrm{l}^{-1}$

\section{The Effect of $\mathrm{H}_{2} \mathrm{O}_{2}$ Dose on the Performance of Fenton Process}

To make Fenton process viable with other processes it is essential that its application should represent a low cost operation, which basically implies a better control of $\mathrm{H}_{2} \mathrm{O}_{2}$ dosage. The effect of initial $\mathrm{H}_{2} \mathrm{O}_{2}$ concentration on treatment efficiency was investigated by varying $\mathrm{H}_{2} \mathrm{O}_{2}$ concentration $\left(0.6 \mathrm{ml} \mathrm{l}^{-1}, 0.8 \mathrm{ml} \mathrm{I}^{-1}\right.$ and $\left.1.0 \mathrm{ml} \mathrm{l}^{-1}\right)$ while keeping optimal iron dose of $40 \mathrm{mg} \mathrm{l}^{-1}$ at $\mathrm{pH}$. Fenton treatment was carried out to optimize the $\mathrm{H}_{2} \mathrm{O}_{2}$ dose again as a cross check. Results (Figure 5) show that the dose of $0.8 \mathrm{ml} \mathrm{I}^{-1}$ was optimal for black effluent. Color and COD removal was maximum as more $\mathrm{OH} \bullet$ radicals were produced at this dose (Bali et al., 2004).
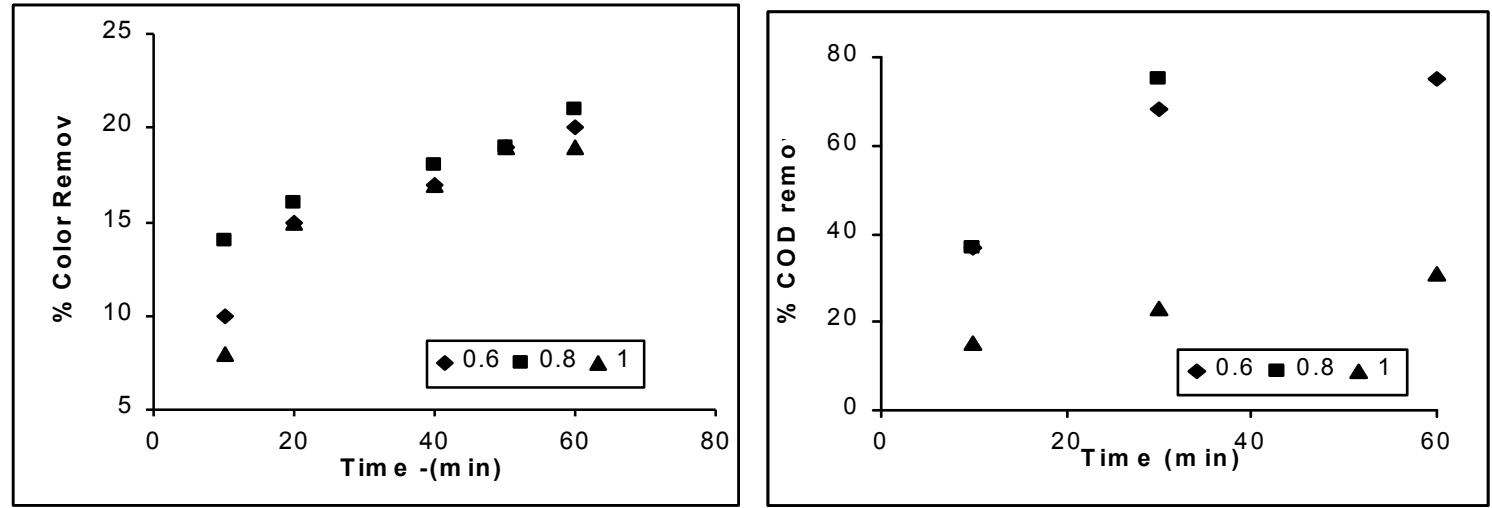

Figure 5. Color and COD removal efficiency of Fenton for black effluent at $\mathrm{pH} 7$ and $\mathrm{FeSO}_{4} 40 \mathrm{mg} \mathrm{l}^{-1}$ and varying $\mathrm{H}_{2} \mathrm{O}_{2}$ Dose $\left(0.6,0.8\right.$ and $\left.1.0 \mathrm{ml} \mathrm{I}^{-1}\right)$ 
The Effect of varying $\mathrm{pH}$ on Color and COD Removal by Fenton Process

The $\mathrm{pH}$ of effluent is an important parameter, which influence the performance of Fenton's process as $\mathrm{pH}$ controls the production rate of hydroxyl radicals. While treating blue effluent with Fenton, the $\mathrm{pH}$ was varied from 3 to 9 (Figure 6). At pH 3 maximum color and COD removal of $45 \%$ and $63 \%$, respectively was observed. Several researches (Neamtu et al., 2003; Hsueh et al., 2005 Lucas and Peres, 2007; Yasar et al., 2007a) reported the similar results at the same $\mathrm{pH}$. But further increase in the $\mathrm{pH}$ from 5 to 9 , decreases the color removal efficiency from $45 \%$ to $11 \%$ and COD removal efficiency from $63 \%$ to $37 \%$. The decrease in the color and COD removal efficiencies is due to the coagulation of hydroxyl complex of ferric, formed during the reaction (Solzhenko et al., 1995) as both ferrous and ferric ions precipitate out during the reaction. Fenton Process also works well at neutral $\mathrm{pH} 7$ and found to be favorable for the degradation of pollutant molecules when there is more cationic concentration in the effluent (Alaton et al., 2001). Figure 7 shows that maximum color and COD removal of $22 \%$ and $81 \%$, which was observed at $\mathrm{pH} 7$ in case of black effluent.
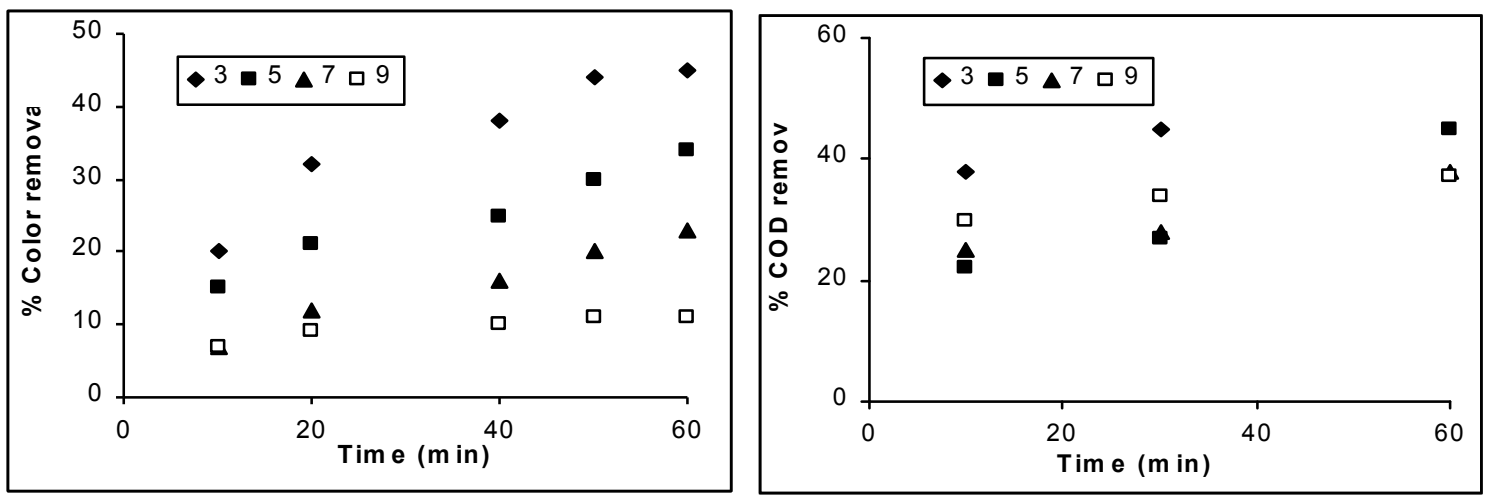

Figure 6. Efficiency of Fenton on \% age color and $\mathrm{COD}$ removal for blue effluent at optimal dose of $\mathrm{H}_{2} \mathrm{O}_{2}=1.0 \mathrm{ml} \mathrm{l}^{-1}$ and $\mathrm{FeSO}_{4}=50 \mathrm{mg} \mathrm{l}^{-1}$ at various $\mathrm{pH}(3,5,7$ and 9$)$
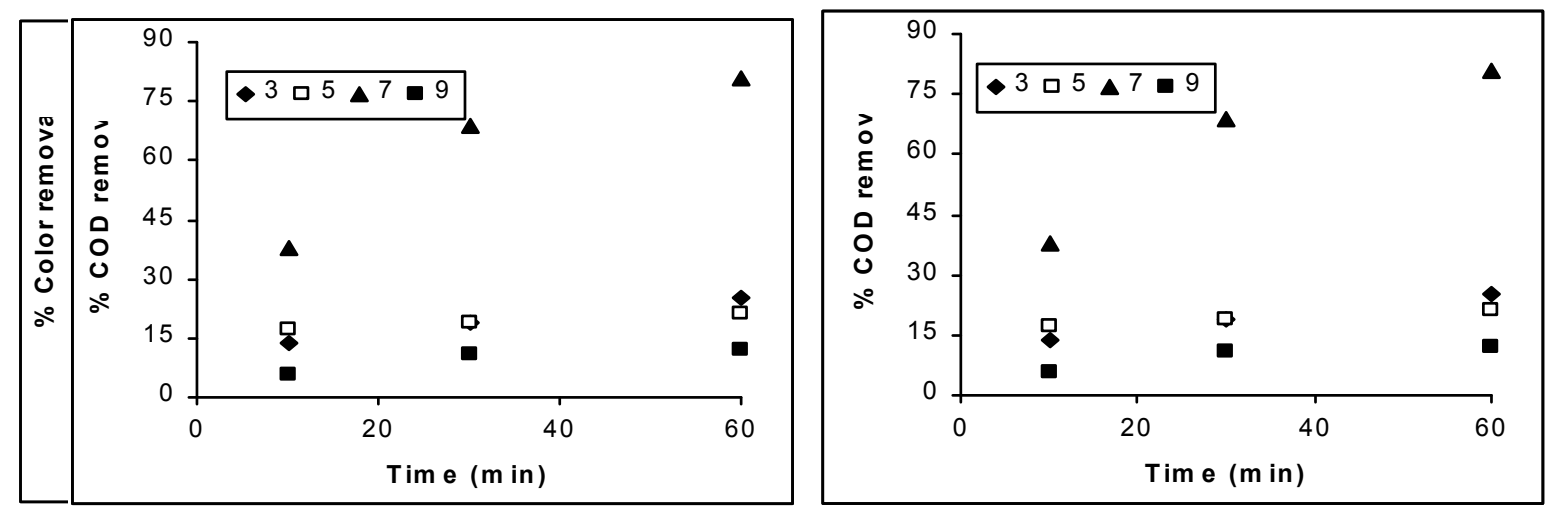

Figure 7. Efficiency of Fenton on \% age color and COD removal for black effluent at optimal dose of $\mathrm{H}_{2} \mathrm{O}_{2}=1.0 \mathrm{mll}^{-1}$ and $\mathrm{FeSO}_{4}=50 \mathrm{mg} \mathrm{l}^{-1}$ at various $\mathrm{pH}(3,5,7$ and 9$)$

\section{The Efficiency of Photo-Fenton Process}

Figures 8 and 9 represent the color and COD efficiency of Photo-Fenton Process when UV source was a low-pressure lamp. UV irradiation between 60 to 80 minutes showed substantial color and COD reduction (56\% and $66 \%$ for blue effluent and $39 \%$ and $84 \%$ for black effluent) because of the ability of the process to generate more hydroxyl radicals leading to the high rate of degradation of organic pollutants coupled with the enhancement of removal efficiency due to iron salt solubility (Bali et al., 2004). After treatment a slight residual color of the effluent owes to the compounds such as dissolved iron or ferro-organo complexes. 

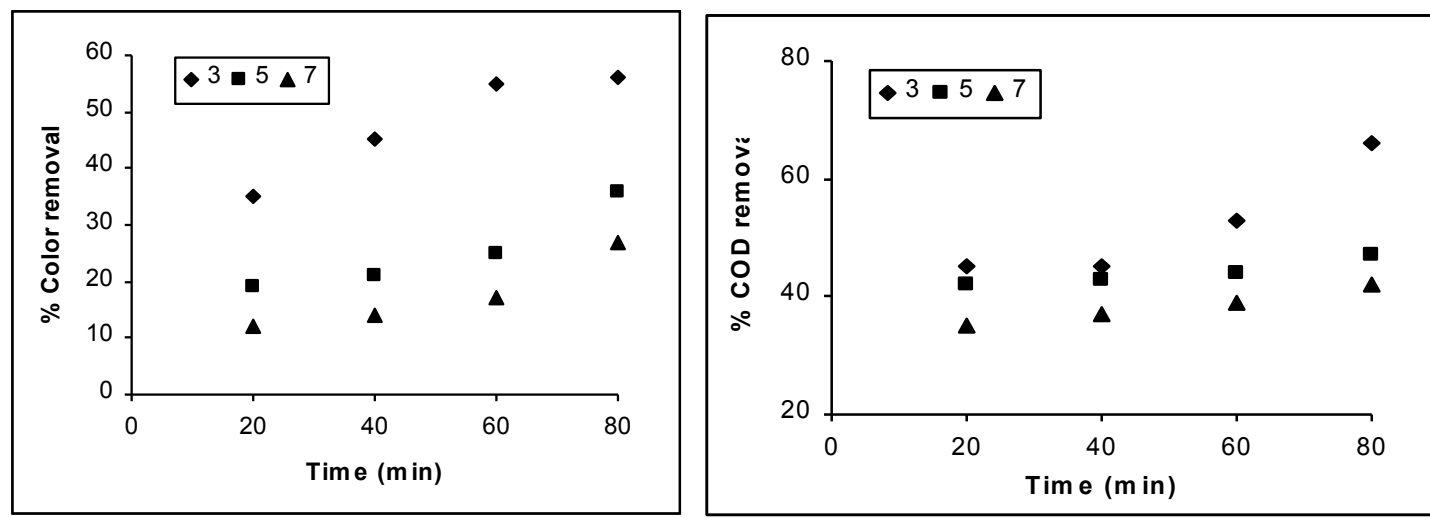

Figure 8. Efficiency of Photo-Fenton on \% age color and COD removal for blue effluent at optimal doses of $\mathrm{H}_{2} \mathrm{O}_{2}=1.0 \mathrm{ml} \mathrm{I}^{-1}$ and $\mathrm{FeSO}_{4}=50 \mathrm{mg} \mathrm{l}^{-1}$ at various $\mathrm{pH}(3,5$ and 7$)$
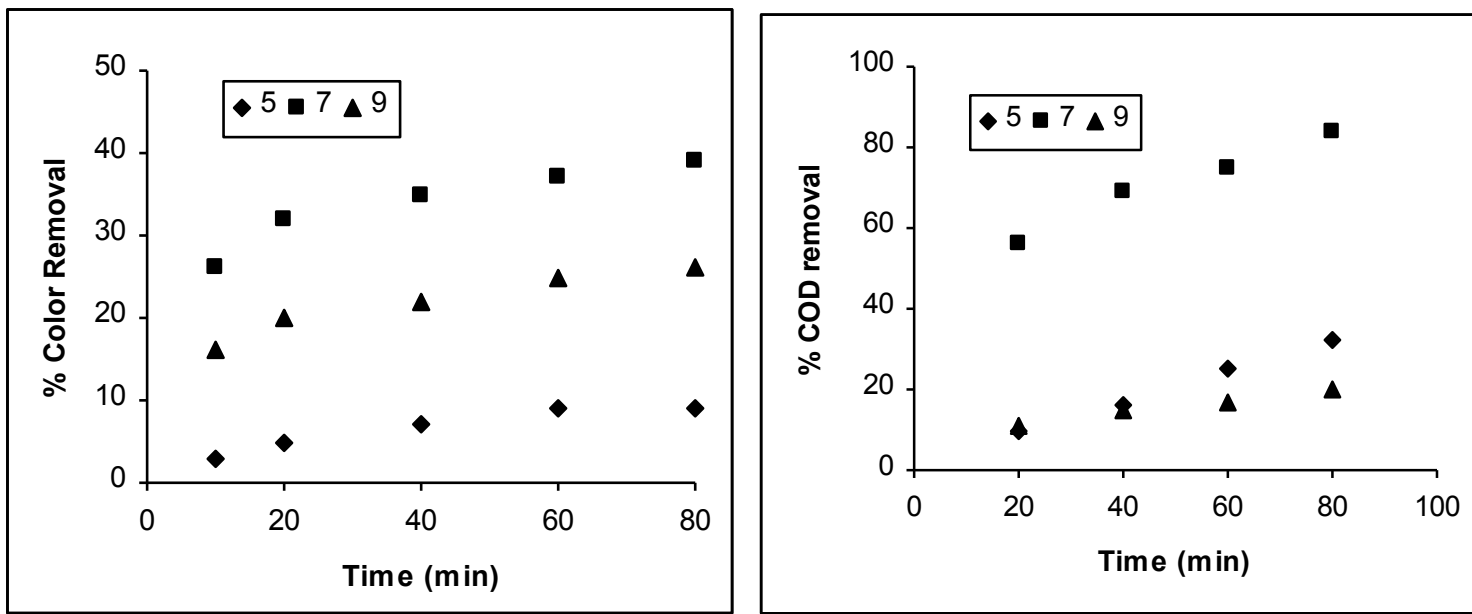

Figure 9. Efficiency of Photo-Fenton on $\%$ age color and COD removal for black effluent at optimal doses of $\mathrm{H}_{2} \mathrm{O}_{2}=0.8 \mathrm{ml}^{-1}$ and $\mathrm{FeSO}_{4}=40 \mathrm{mg} \mathrm{l}^{-1}$ at various $\mathrm{pH}(5,7$ and 9$)$

Tables 3 and 4 show the efficiency of Photo-Fenton Process with UV source as Sunlight. Color and COD removal efficiency was $61 \%$ and $85 \%$ for blue effluent and $52 \%$ and $88 \%$ for black effluent respectively after 18 hours exposure to sunlight. The solar light proved to be better for color and COD reduction for the both effluents as compared to UV lamp (Hu et al., 2003).

Table 3. Efficiency of Photo-Fenton on \% age color and COD removal for blue effluent at optimal doses of $\mathrm{H}_{2} \mathrm{O}_{2}=1.0 \mathrm{ml} \mathrm{I}^{-1}$ and $\mathrm{FeSO}_{4}=50 \mathrm{mg} \mathrm{l}^{-1}$ at $\mathrm{pH} 3$ and UV source was Sunlight

\begin{tabular}{ccccc}
\hline Days & $\begin{array}{c}\text { Time } \\
\text { (Hours) }\end{array}$ & $\begin{array}{c}\text { Light intensity } \\
\text { (Watt) }\end{array}$ & $\begin{array}{c}\text { Color removal } \\
(\%)\end{array}$ & $\begin{array}{c}\text { COD removal } \\
(\%)\end{array}$ \\
\hline \multirow{2}{*}{1} & 2 & 1.3 & 20.0 & 52.0 \\
\cline { 2 - 5 } & 4 & 1.0 & 21.0 & 56.0 \\
\cline { 2 - 5 } & 6 & 0.3 & 24.0 & 60.0 \\
\hline \multirow{2}{*}{2} & 8 & 1.7 & 27.0 & 67.0 \\
\cline { 2 - 5 } & 10 & 1.8 & 31.0 & 74.0 \\
\hline \multirow{2}{*}{3} & 12 & 1.4 & 32.0 & 78.0 \\
\cline { 2 - 5 } & 14 & 1.4 & 37.0 & 82.0 \\
\cline { 2 - 5 } & 16 & 1.4 & 46.0 & 83.0 \\
\hline
\end{tabular}


Table 4. Efficiency of Photo-Fenton on \% age color and COD removal for black effluent at optimal doses of $\mathrm{H}_{2} \mathrm{O}_{2}=0.8 \mathrm{ml} \mathrm{l}^{-1}$ and $\mathrm{FeSO}_{4}=40 \mathrm{mg} \mathrm{l}^{-1}$ at $\mathrm{pH} 7$ and UV source was Sunlight

\begin{tabular}{ccccc}
\hline Days & $\begin{array}{c}\text { Time } \\
\text { (Hours) }\end{array}$ & $\begin{array}{c}\text { Light intensity } \\
\text { (Watt) }\end{array}$ & Color removal (\%) & $\begin{array}{c}\text { COD removal } \\
(\%)\end{array}$ \\
\hline 1 & 2 & 1.6 & 30.0 & 25.0 \\
\cline { 2 - 5 } & 4 & 1.5 & 38.0 & 42.0 \\
\cline { 2 - 5 } & 6 & 0.5 & 42.0 & 49.0 \\
\hline 2 & 8 & 1.2 & 47.0 & 59.0 \\
\cline { 2 - 5 } & 10 & 0.8 & 49.0 & 69.0 \\
\hline 3 & 12 & 0.4 & 50.0 & 75.0 \\
\cline { 2 - 5 } & 14 & 1.2 & 51.0 & 81.0 \\
\cline { 2 - 5 } & 16 & 0.6 & 52.0 & 82.0 \\
\hline
\end{tabular}

\section{Ozonation}

Ozone is considered to be highly feasible and promising to decolorize wastewater among all AOP's (Arslan et al., 2000) and has proved a potential alternative for COD removal but it is very costly. Table 5 and Figure 10 display the efficiency of ozonation process for color and COD removal. Increase in color and COD removal is evident with increase in ozonation time. At pH 5 and 20 min ozone exposure time there was almost $100 \%$ color and COD removal in case of blue effluent. However, black effluent proved slightly resistant, and showed color and COD removal of $98 \%$ and $69 \%$, respectively at ozone exposure time of $60 \mathrm{~min}$. Reaction $\mathrm{pH}$ also influences on the performance of the ozonation process as it works very well both in acidic (Neamtu et al., 2003) and alkaline pH (Sevimli and Kinaci, 2002 ;Yasar et al., 2007b). Complete decolorization was achieved at $\mathrm{pH} 5$ because of the direct reactivity of ozone molecule with the effluent. High color and COD removal $(100 \%$ color and COD removal in case of blue effluent and $100 \%$ color and $87 \%$ COD removal in case of black effluent) at $\mathrm{pH} 9$ can be attributed to the maximum generation of hydroxyl radicals (Konsowa, 2003). In fact, at neutral pH less color and COD removal at first 10 min of ozonation is because of the fact that production of hydroxyl radical was less and it didn't act as molecular ozone.

Table 5. Efficiency of Ozonation on $\%$ age color and COD removal for blue effluent at various $\mathrm{pH}$

\begin{tabular}{|c|c|c|c|c|}
\hline \multirow[t]{2}{*}{$\mathrm{pH}$} & \multicolumn{2}{|c|}{$\begin{array}{l}\text { Color removal (\%) at time } \\
(\min )\end{array}$} & \multicolumn{2}{|c|}{$\begin{array}{c}\text { COD removal }(\%) \text { at time } \\
(\min )\end{array}$} \\
\hline & 10 & 20 & 10 & 20 \\
\hline 5 & 99.0 & 100.0 & 85.0 & 100.0 \\
\hline 7 & 89.0 & 99.0 & 86.0 & 97.0 \\
\hline 9 & 99.0 & 100.0 & 86.0 & 100.0 \\
\hline 10 & 99.0 & 100.0 & 86.0 & 100.0 \\
\hline
\end{tabular}
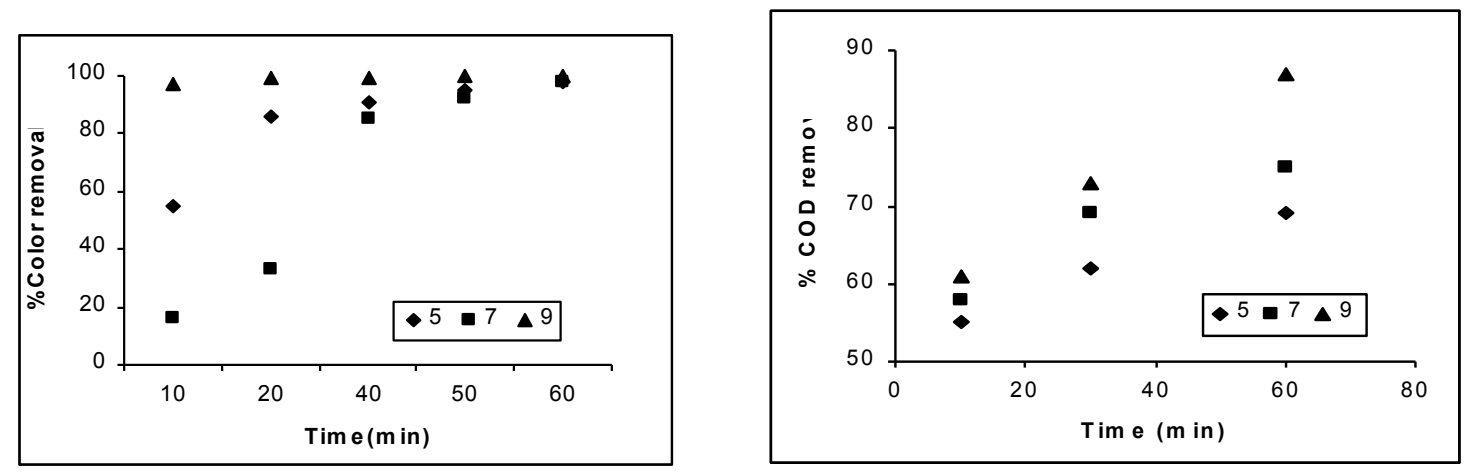

Figure 10. Efficiency of Ozonation on \% age color and COD removal for black effluent at various $\mathrm{pH}(5,7$ and 9$)$ 


\section{Comparison of Energy Requirements for Color and COD Removal of Ice Blue and Black Dye Solutions with AOP's}

In energy intense treatment process such as ozone and UV induced photochemical processes like Photo-Fenton, the design variables, i.e., exposure to UV radiation and order of magnitude of contaminant concentration removal can be combined into a single function, Electrical Energy per Order of Pollutant Removal (EE/O). The EE/O is powerful scale up parameter and a measure of the treatment rates obtained in a fixed volume of contaminated water as a function of the applied specific energy.

Table 6. Comparison of Electrical Energy requirements \& operating Cost by different processes of AOP's used for Blue effluent

\begin{tabular}{|c|c|c|c|c|c|c|}
\hline \multirow[t]{2}{*}{ Process } & \multicolumn{3}{|c|}{ Color } & \multicolumn{3}{|c|}{ COD } \\
\hline & $\begin{array}{c}\% \\
\text { Removal }\end{array}$ & $\begin{array}{c}\mathrm{EE} / \mathrm{O} \\
\left(\mathrm{kWh} \mathrm{m}^{-3}\right)\end{array}$ & $\begin{array}{c}\text { Cost } \\
\left(\$ \mathrm{~m}^{-3}\right)\end{array}$ & $\begin{array}{c}\% \\
\text { Removal }\end{array}$ & $\begin{array}{c}E E / O \\
\left(\mathrm{kWh} \mathrm{m}^{-3}\right)\end{array}$ & $\begin{array}{c}\text { Cost } \\
\left(\$ \mathrm{~m}^{-3}\right)\end{array}$ \\
\hline $\mathrm{H}_{2} \mathrm{O}_{2}$ & 21.0 & 8.0 & 0.3 & 32.0 & 8.0 & 0.3 \\
\hline Fenton & 45.0 & 0.7 & 0.03 & 63.0 & 0.8 & 0.03 \\
\hline Photo-Fenton (lamp) & 56.0 & 43.0 & 9.0 & 66.0 & 46.0 & 9.8 \\
\hline Photo- Fenton (sunlight) & 61.0 & 0.3 & 0.01 & 85.0 & 0.4 & 0.02 \\
\hline Ozonation & 100.0 & 38.0 & 8.0 & 100.0 & 38.0 & 8.0 \\
\hline
\end{tabular}

Table 7. Comparison of Electrical Energy requirements \& operating Cost by different processes of AOP's used for Black effluent

\begin{tabular}{lcccccc}
\hline \multicolumn{1}{c}{ AOP's } & \multicolumn{3}{c}{ Color } & & \multicolumn{3}{c}{ COD } \\
& $\begin{array}{c}\% \\
\text { Removal }\end{array}$ & $\begin{array}{c}\mathrm{EE} / \mathrm{O} \\
\left(\mathrm{kWh} \mathrm{m}^{-3}\right)\end{array}$ & $\begin{array}{c}\text { Cost } \\
\left(\$ \mathrm{~m}^{-3}\right)\end{array}$ & $\begin{array}{c}\% \\
\text { Removal }\end{array}$ & $\begin{array}{c}\mathrm{EE} / \mathrm{O} \\
\left(\mathrm{kWh} \mathrm{m}^{-3}\right)\end{array}$ & $\begin{array}{c}\text { Cost } \\
\left(\$ \mathrm{~m}^{-3}\right)\end{array}$ \\
\hline $\mathrm{H}_{2} \mathrm{O}_{2}$ & 21.0 & 8.0 & 0.3 & 44.0 & 8.0 & 0.3 \\
\hline Fenton & 21.8 & 0.66 & 0.03 & 81.0 & 0.98 & 0.04 \\
\hline Photo-Fenton (UV lamp) & 39.0 & 40.0 & 8.2 & 84.0 & 59.5 & 13.0 \\
\hline Photo- Fenton (sunlight) & 52.0 & 0.3 & 0.01 & 88.0 & 0.5 & 0.02 \\
\hline Ozonation & 100.0 & 19.5 & 4.0 & 87.0 & 33.4 & 7.3 \\
\hline
\end{tabular}

It is apparent from Table 6 and 7 that for blue and black effluent photochemical process (UV lamp) consumes more electrical energy as compared to non-photochemical processes. Photo-Fenton's process (sunlight) seemed to show a satisfactory color and COD and to be economically more viable choice. Fenton proved to be the second best option in terms of energy consumption and color and COD removal.

\section{CONCLUSIONS}

Following conclusions have been drawn from the study,

- $\mathrm{H}_{2} \mathrm{O}_{2}$ alone was not efficient for decolorization and COD reduction of textile effluent because of less oxidation potential and scavenging effect of $\mathrm{H}_{2} \mathrm{O}_{2}$ beyond a certain dose. The performance of $\mathrm{H}_{2} \mathrm{O}_{2}$ as an oxidant was slightly enhanced by the addition of iron salt to the effluent in the Fenton process.

- Photo-Fenton process via UV lamp considerably removed the color and COD. While Ozonation was proved to be highly feasible and promising technique to decolorize and reduce COD from textile effluent but at very high cost. Photo-Fenton (sunlight) proved to be the most cost effective and efficient procedure for the color and COD removal among all AOP's, whereas Fenton process to be the second best option. The electrical energy requirements of the tested processes followed the increasing order UV/Fe/ $\mathrm{H}_{2} \mathrm{O}_{2}<\mathrm{O}_{3}<\mathrm{H}_{2} \mathrm{O}_{2}$ $<\mathrm{Fe} / \mathrm{H}_{2} \mathrm{O}_{2}<\mathrm{UV}$ (solar).

\section{ACKNOWLEDGEMENTS}

The authors are thankful to the Director Institute of Geology, University of the Punjab for providing the research facilities and also grateful to Professor Emeritus (Former Director of Department of Earth Sciences) for his help in every aspect. 


\section{REFERENCES}

Alaton I.A. (2003). A Review of The Effects of Dye Assisting Chemicals on Advanced Oxidations of Reactive Dyes in Wastewater, Coloration Technology, 119(6), 345-352.

Alaton I.A., Balcioglu I.A., Bahnemann D.W. (2001). Advanced Oxidation of a Reactive Dye Bath Effluent: Comparison of $\mathrm{O}_{3}, \mathrm{H}_{2} \mathrm{O}_{2} / \mathrm{UV}-\mathrm{C}$ and $\mathrm{TiO}_{2} / \mathrm{UV}$-A Process, Water Research, 36(5), 1143-1153.

Aleboyeh A., Yasser Y., Aleboyeh H. (2005). Kinetics of Oxidative Decolorization of Acid Orange 7 in Water by Ultraviolet Radiation, J. Sep. Purif. Technol., 43, 143-148.

Arslan I., Balcioglu A.I., Tuhkanen T. (2000). Advanced Treatment of Dyehouse Effluents by $\mathrm{Fe}(\mathrm{II})$ and $\mathrm{Mn}(\mathrm{II})-$ Catalyzed Ozonation and the $\mathrm{H} 2 \mathrm{O} 2$ Process, J. Water Sci. Technol, 42, 13-18.

Arslan-Alaton I., Gursoy B.H., Schmidt J.E. (2008). Advanced oxidation of acid and reactive dyes: Effect of Fenton treatment on aerobic, anoxic and anaerobic processes, Dyes and Pigments, 78, 117-30.

Azbar N., Yonas T., Kestoiglu K. (2004). Comparison of Various Method for COD and Color Removal from a Polyester and Acetate Fiber Dying Effluent, Chemosphere, 55, 35-43.

Balcioglu I.A., Arslan I. (2001). Partial Oxidation of Reactive Dyestuffs and Synthetic Textile Dye-Bath by the $\mathrm{O} 3$ and $\mathrm{H} 2 \mathrm{O} 2$ Processes, J. Water Sci. Technol, 43(2), 221-222.

Bali U., Catalkaya E., Sengul F. (2004). Photo Degradation of Reactive Black 5, Direct Red 28 and Direct Yellow 12 using UV, UV/ $\mathrm{H}_{2} \mathrm{O}_{2}$ and $\mathrm{UV} / \mathrm{H}_{2} \mathrm{O}_{2} / \mathrm{Fe}^{+2}$ : A Comparative Study, Journal of Hazardous Materials, 114(1-3), 159-166.

Georgiou D., Melidis P., Aivasidis A., Gimouhopoulos K. et al., (2002). Degradation of Azo-Reactive Dyes by Ultraviolet Radiation in the Presence of Hydrogen Peroxide, Dyes and Pigments, 52(2), 52-69.

Hsueh C.L., Huang Y.H., Wang C.C., Chen C.Y. (2005). Degradation of Azo Dyes Using Low Iron Concentration of Fenton and Fenton Like System, Chemosphere, 58, 1409-14.

Hu E., Li Y., Zou L. (2003). Solar Powered Color Removal of Dyes Using Ferrioxalate/H2O2, Solar 2004: life, the universe \& renewables: Proceedings of the $42^{\text {nd }}$ Annual, 30 November-3 December 2004 / Lyon, Katrina (ed.)

Huanga Y.H., Huanga Y.F., Changa P.S. (2008). Comparative study of oxidation of dye-Reactive Black B by different advanced oxidation processes: Fenton, electro-Fenton and photo-Fenton, $J$ Hazardous Materials, 154, 655-62.

Konsowa A.H. (2003). Decolorization of Wastewater Containing Direct Dye by Ozonation in a Batch Bubble Column Reactor, Desalination, 158(1-3), 233-240.

Lucas S.M., Peres A.J. (2007). Degradation of Reactive Black 5 by Fenton/UV-C and ferrioxalate/H2O2/solar light processes, Dyes and Pigments, 74, 622-29.

Moreira M.T., Mielgo I., Feijoo-Lena J.M. (2000). Evaluation of Different Fungal Strains in Decolorization of Synthetic Dyes, J. Biotechnol. Lett., 22, 1449-1503.

Neamtu M., Siminiceanu I., Yediler A., Kettrup A. (2003). Oxidation of Commercial Reactive Azo Dye Aqueous Solution by the photo Fenton and Fenton like Processes, J. Photochem. A: Photobiol. A: Chemistry, 161, 87-93.

Pavlostathis S.G., Beydilli M.I. (2005). Decolorization Kinetics of the Azo Dye Reactive Red 2 under Methanogenic Conditions: Effect of Long-Term Culture Acclimation, Biodegradation, 16(2), 135-46.

Sevimli M., Kinaci C. (2002). Decolorization of Textile Wastewater By Ozonation And Fenton's Process, $J$ Water Sci. Technol., 45, 279-286.

Shah V., Verma P., Stopka P., Gabriel J., Baldriana P., Nerud F. (2003). Decolorization of Dyes with Copper(II)/Organic Acid/Hydrogen Peroxide Systems, J. Applied Catalysis B: Environ., 46, 287292.

Solozhenko E.G., Soboleva N.M., Goncharuk V.V. (1995). Decolourization of Azodye Solutions by Fenton's Oxidation, J. Water Res., 29(9), 2206-2210.

Wadley S., Waite T.D. (2002). Photo-Fenton Oxidation of Pesticides. Environment 2002 Convention and Exhibition and IWA 3rd World Water Congress, Melbourne, Australia, 7-12 April, pp. 569-574.

Yasar A., Ahmad N., Khan A.A.A. (2007a). Decolourisation of Blue CL-BR dye by AOPs using bleach wastewater as source of H2O2, J. Environmental Sciences, 19, 1183-88.

Yasar A., Ahmad N., Rehman M.S. (2007b). Ozone for color and COD removal of raw and anaerobically biotreated combined industrial wastewater, Polish J. Environmental Studies, 16, 289-94.

Yasar A., Nasir A., Aamir A.A.K. (2006). Energy requirement of UV and AOPs for the post treatment of UASB treated combined industrial effluent, Color Technol., 122(4), 201-206. 